\title{
Morphofunctional state of rat kidneys under the conditions of cisplatin-induced acute kidney injury and its correction by melatonin
}

\author{
Ye.A. Dudka, T.S. Shchudrova, A.Ye. Petriuk, I.I. Zamorskii \\ Higher State Educational Establishment of Ukraine "Bukovinian State Medical University”, \\ Chernivtsi; e-mail: igor.zamorskii@gmail.com
}

\begin{abstract}
In experiments on laboratory nonlinear white mature rats, the effect of melatonin $(5 \mathrm{mg} / \mathrm{kg})$ on the morphofunctional state of kidneys under the conditions of cisplatin-induced acute kidney injury was studied. It was found that single administration of cisplatin at a dose of $6 \mathrm{mg} / \mathrm{kg}$ causes necrosis and disseminated degenerative changes of tubular cells with the development of oliguric form of toxic nephropathy, which is accompanied by a decrease in diuresis by 2.9 times, a reduction of glomerular filtration rate by 5 times, an increase in plasma creatinine level by 2.2 times, a significant proteinuria and decreased tubular reabsorption capacity. It was established that the use of melatonin in the prophylactic-therapeutic regimen demonstrates a cytoprotective effect in relation to the epitheliocytes of the renal tubules, significantly limiting the degree and prevalence of histopathological changes, and thus preventing the development of oliguria, as evidenced by a significant increase in diuresis by 1.8 times, glomerular filtration rate - by 2,6 times comparing to untreated animals; prevention of retention azotemia, hypokalemia, and significant loss of sodium ions, reducing proteinuria by 1.7 times and activating ammoniagenesis. The research results prove the prospects of the further studies to investigate the nephroprotective potential of melatonin under the conditions of renal pathology of different genesis.

Key words: cisplatin-induced acute kidney injury; melatonin; nephroprotection.
\end{abstract}

\section{INTRODUCTION}

Nowadays, the in-depth study of the influence of pineal hormone melatonin on the various systems of the organism, both in physiological and pathological conditions, as well as the study of the possibilities of its use as a drug for the purpose of prevention and treatment of numerous pathologies is becoming increasingly relevant $[1,2]$. The main physiological function of melatonin is the synchronization of circadian rhythms of biological functions (sleep-wake cycle, reproduction, synthesis of paracrine and endocrine hormones, numerous metabolic processes, blood pressure, etc.), which results in its therapeutic use as a sedative-hypnotic drug, as a remedy for prophylaxis of jet lag syndrome, as well as a geroprotector [1-3].

Besides, melatonin acts as a powerful antioxidant due to its ability to penetrate membranes (C) Ye.A. Dudka, T.S. Shchudrova, A.Ye. Petriuk, I.I. Zamorskii and physiological barriers, scavenge reactive oxygen and nitrogen species, and regulate the activity of antioxidant enzymes [4]. The antioxidant properties of melatonin determine the prospect of studying the possibilities of its use in a wide range of pathological states accompanied by the development of oxidative stress $[1,5,6]$. The radioprotective effect of melatonin, as well as its ability to inhibit carcinogenesis, has been also established. Moreover, melatonin exhibits immunomodulatory, anti-inflammatory and analgesic effects, due to its ability to interact with immunocompetent cells and regulate the synthesis of cytokines [7, 8]. An important advantage of melatonin as a drug is a minimal risk of side effects, even when a high-dose therapy or a long-term treatment is used [9]. Multiple effects of melatonin, as well as its ability to affect the main pathogenetic links of the 
pathological process, give rise to the numerous experimental and clinical researches into the mechanisms of action and organoprotective potential of exogenous melatonin under the conditions of various pathologies, including renal [10-12].

The numerous research results indicate the possible efficacy of melatonin as a cytoprotector in a number of acute (toxic and ischemic injury of liver, kidneys, or brain) and chronic pathologies (metabolic and neurodegenerative diseases, oncopathology, inflammation, aging) $[1,3,5,9]$.

The importance and relevance of conducting our research in this direction is determined by the continuous increase in the number of patients with acute kidney injury (AKI) and chronic kidney disease (CKD). This, in particular, is caused by the frequent use in clinical practice of a number of drugs with nephrotoxic side effects [13]. Among such agents, in anticancer chemotherapy relatively commonly is used cisplatin, which is characterized by a significant nephrotoxicity, observed in a third of patients. For this reason, the search for and the introduction into clinical practice of drugs capable of preventing or limiting the toxic effects of cisplatin is an issue of current importance [14-16]. Initially, the nephrotoxicity of cisplatin is associated with the development of oxidative stress - one of the most important links in the pathogenesis of cisplatin-induced kidney injury. The main target for cisplatin is the mitochondria of the renal proximal tubular cells, where it causes a dysfunction of the respiratory chain and generation of reactive oxygen species, which is closely related to the development of cellular energy deficiency and disturbances of aerobic metabolism with the further progression of pathological changes [14, 15]. Since it has been proved that melatonin is the most potent mitochondrial antioxidant, the rationale for its use as a cytoprotector under the given conditions is not in doubt $[16,17]$. Several studies also indicate the synergistic antitumor activity of melatonin when used in combination with chemotherapeutic agents, combined with its ability to potentiate the effects of antitumor agents (including cisplatin), while reducing the severity of their adverse effects [18].

Consequently, taking into consideration the relevance and prospects for establishing a sufficient evidence base for the introduction of melatonin into clinical practice as a remedy for prevention and reduction the cisplatin toxicity, based on the presence of its potent antioxidant and cytoprotective properties, as well as the low risk of side effects, the aim of our research was to study the morphofunctional state of rat kidneys under the conditions of cisplatin-induced AKI against the background of melatonin administration in the prophylactictherapeutic treatment regimen.

\section{METHODS}

Experiments were carried out on 30 nonlinear mature white rats weighing 150-200 g, which were maintained under the standard vivarium conditions at constant temperature and humidity, free access to water and food (full value fodder for the laboratory animals). The animals were randomly divided into 3 groups $(n=7)$ : group I - intact control, group II - cisplatin-induced AKI caused by a single intraperitoneal injection of cisplatin ("EBEWE Pharma", Austria) at a dose of $6 \mathrm{mg} / \mathrm{kg} 72$ hours prior to completion of the experiment [19]. Animals of the III group were administered with melatonin at a dose of $5 \mathrm{mg} / \mathrm{kg}$ ("Sigma", USA) for 4 days prior to and 3 days after cisplatin administration. For evaluation of the functional state of kidneys, $24 \mathrm{~h}$ after last melatonin injection, urine was collected for $2 \mathrm{~h}$ under the conditions of induced water load (enteral administration of drinking water heated to $37^{\circ} \mathrm{C}$ in the amount of $5 \%$ of body weight using an intragastric tube). Animals were sacrificed under the light anesthesia, while blood, urine samples and kidneys were collected for biochemical and histopathological assessments.

All interventions were conducted in accordance with the criteria outlined in the European 
Union Directive 2010/63/EU «On the protection of animals used for scientific purposes» (2010).

The excretory kidney function was evaluated by the indices of diuresis, glomerular filtration rate (GFR), plasma and urine creatinine level, urine protein concentration and excretion. Plasma and urine creatinine levels were determined using the Jaffe reaction, urine protein level - using the sulfosalicylic acid precipitation test.

The ion-regulatory kidney function was assessed by the indices of concentration and excretion of sodium ions with urine, reabsorption, proximal, distal transport of sodium ions, concentration and excretion of potassium ions with urine. Sodium and potassium plasma and urine levels were determined using electronic flame photometry method. The acidregulatory function of kidneys was estimated by the indices of the hydrogen ions, titrated acids and ammonium ions excretion, their urine content was determined by titration of a sodium bicarbonate solution [20]. Standardization of kidney function indices was performed by recalculation of their absolute values per unit of body weight or by $100 \mu$ l of glomerular filtrate.

To conduct a histological examination the kidneys of rats were fixed in 10\% formalin, embedded in paraffin, sectioned at $5 \mathrm{mM}$ and then stained with hematoxylin and eosin. The preparations were evaluated using light microscopy and photographed (Olympus C740UZ photo camera, Japan, LUMAM-R8 microscope, LOMO, Russian Federation). Documentation of the pathological processes was performed by the computer morphometry of objects in histological preparations using computer software "VideoTest - Razmer 5.0" (LLC "VideoTest", Russian Federation).

Statistical analysis of the data was performed using SPSS 17.0 software. All data are represented as a mean \pm standard error of the mean $(\mathrm{M} \pm \mathrm{m})$. A character of distribution within group was determined using Kolmogorov-Smirnov test. Estimation of the differences between the samples was conducted using parametric Student's t-test (for normal distribution) and nonparametric Mann-Whitney $U$ test (when the assumptions of the t-test were not met). The values $\mathrm{P}<0.05$ were considered statistically significant.

\section{RESULTS AND DISCUSSION}

The development of cisplatin-induced AKI was accompanied by the significant changes in the functional state of rat kidneys due to accumulation of the drug in the proximal tubular cells (Table). As a consequence of cisplatin toxicity, there was a damage to cells of the tubular apparatus of nephron with the development of energy deficiency, which caused an inhibition of the activity of membrane transport systems and disorders in the processes of ion reabsorption in the proximal and distal tubules, manifested by an increase in the excretion of sodium and potassium ions.

An increase in the urine sodium level resulted in the activation of the tubularglomerular feedback with a decrease in the renal blood flow and subsequent reduction of GFR. As a result, in animals with cisplatin-induced AKI there was a decrease in diuresis by 2.9 times, indicating the development of the oliguric stage of AKI, with a related fall in GFR by 5 times, and reduction of water reabsorption by $4.6 \%$. Consequently, the creatinine excretion decreased by 2.3 times, which was accompanied by an increase in plasma creatinine level by 2.2 times and development of retention azotemia. A significant damage to nephrocytes and reduction of the tubular reabsorption capacity led to the development of a marked proteinuria with an increase in urine protein level by 3.9 times, urine protein excretion - by 6.9 times. On the part of the acid-regulatory kidney function there was a decrease in urine $\mathrm{pH}$, which was accompanied by an increase in titrated acids excretion by 2.2 times, and a decrease in ammoniagenesis by 1.8 times, indicating a reduction in kidney ability to compensate for acidosis. Disturbances of the ion-regulatory kidney function were manifested by an increase in sodium ions level in urine by 
3.4 times, and their excretion - by 1.2 times.

This can be explained by a reduction of the absolute reabsorption of sodium ions by 5.3 times, with a decrease in proximal transport by 5.6 times, distal - by 3.1 times. As a result, a fractional excretion of sodium ions increased to $2.8 \%$, which confirms a significant toxic damage to the proximal tubular nephrocytes. The progression of the AKI was accompanied by an enhanced renal potassium loss with an increase in its excretion by 6 times, due to the growing influence of aldosterone on the distal part of nephron. At the same time, a 1.3-fold decrease in the plasma potassium level indicates the development of hypokalemia - a characteristic side effect of the therapy with cisplatin.
The obtained data correlate with the results of a morphological study on the histopathological signs of renal tissue damage 72 hours after cisplatin administration, which was evaluated by the changes in glomeruli, degree of tubular epithelial cells degeneration, extent of tubular necrosis, presence of luminal casts, and interstitial edema. In the kidneys of animals with cisplatin-induced AKI there are signs of damage to both glomeruli and tubules (Fig. 1). Pathological changes occur in most cells of the proximal tubules, with about $26 \%$ of the epitheliocytes in the state of necrosis, while other cells have signs of dystrophic damage of varying degrees: $64 \pm 1.6 \%$ of cells are in the state of hydropic vacuolation, and $6 \pm 1.7 \%$ are in the

Influence of melatonin $(5 \mathrm{mg} / \mathrm{kg})$ on the functional state of rat kidneys in conditions of cisplatin-induced AKI $(\mathbf{M} \pm \mathbf{m}, \mathbf{n}=7)$

\begin{tabular}{|c|c|c|c|}
\hline Index & Intact control & $\begin{array}{c}\text { Cisplatin-induced } \\
\text { AKI }\end{array}$ & $\begin{array}{c}\text { AKI }+ \\
\text { Melatonin } \\
\end{array}$ \\
\hline Diuresis, $\mathrm{ml} / 2 \mathrm{~h} \times 100 \mathrm{~g}$ & $4.34 \pm 0.11$ & $1.48 \pm 0.09 *$ & $2.64 \pm 0.10 * *$ \\
\hline Plasma creatinine, $\mu \mathrm{mol} / 1$ & $55.97 \pm 2.43$ & $124.74 \pm 4.17 *$ & $96.25 \pm 3.90 * *$ \\
\hline Creatinine excretion, $\mu \mathrm{mol} / 2 \mathrm{~h}$ & $3.93 \pm 0.17$ & $1.72 \pm 0.13 *$ & $3.46 \pm 0.23 * *$ \\
\hline Glomerular filtration rate, $\mu \mathrm{l} / \mathrm{min} \times 100 \mathrm{~g}$ & $587.69 \pm 20.23$ & $115.32 \pm 9.03 *$ & $300.54 \pm 19.44 * *$ \\
\hline Reabsorption of water, $\%$ & $98.81 \pm 0.25$ & $94.20 \pm 0.48^{*}$ & $97.58 \pm 0.27^{* *}$ \\
\hline Urine protein, $g / 1$ & $0.016 \pm 0.001$ & $0.063 \pm 0.008^{*}$ & $0.037 \pm 0.002 * *$ \\
\hline Urine protein excretion, $\mathrm{mg} / 100 \mu \mathrm{l}$ & $0.012 \pm 0.001$ & $0.083 \pm 0.012 *$ & $0.033 \pm 0.002 * *$ \\
\hline Urine $\mathrm{pH}$ & $7.45 \pm 0.05$ & $7.23 \pm 0.04 *$ & $7.41 \pm 0.07$ \\
\hline Titrated acids excretion, $\mu \mathrm{mol} / 2 \mathrm{~h}$ & $21.90 \pm 2.41$ & $48.76 \pm 3.31 *$ & $34.55 \pm 1.62 * *$ \\
\hline Ammonium ions excretion, $\mu \mathrm{mol} / 2 \mathrm{~h}$ & $59.52 \pm 8.33$ & $32.82 \pm 3.50 *$ & $65.33 \pm 5.65 * *$ \\
\hline Urine $\mathrm{Na}^{+}, \mathrm{mmol} / \mathrm{l}$ & $0.78 \pm 0.06$ & $2.64 \pm 0.64 *$ & $2.74 \pm 0.15$ \\
\hline Plasma $\mathrm{Na}^{+}, \mathrm{mmol} / \mathrm{l}$ & $126.43 \pm 5.08$ & $122.50 \pm 5.35$ & $125.71 \pm 4.14$ \\
\hline Filtration fraction of $\mathrm{Na}^{+}, \mu \mathrm{mol} / \mathrm{min}$ & $74.10 \pm 3.35$ & $14.05 \pm 0.97 *$ & $37.57 \pm 2.14 * *$ \\
\hline Absolute $\mathrm{Na}^{+}$reabsorption, $\mu \mathrm{mol} / \mathrm{min}$ & $88.88 \pm 4.02$ & $16.83 \pm 1.16^{*}$ & $45.01 \pm 2.56 * *$ \\
\hline Relative $\mathrm{Na}^{+}$reabsorption, $\%$ & $98.19 \pm 0.22$ & $95.79 \pm 0.27 *$ & $96.67 \pm 0.15$ \\
\hline Fractional excretion of $\mathrm{Na}^{+}, \%$ & $0.46 \pm 0.04$ & $2.82 \pm 0.33^{*}$ & $1.09 \pm 0.08 * *$ \\
\hline Proximal transport of $\mathrm{Na}^{+}, \mathrm{mmol} / \mathrm{min}$ & $69.53 \pm 3.24$ & $12.55 \pm 0.90^{*}$ & $34.83 \pm 2.05^{* *}$ \\
\hline Distal transport of $\mathrm{Na}^{+}, \mu \mathrm{mol} / \mathrm{min}$ & $4.53 \pm 0.20$ & $1.47 \pm 0.09 *$ & $2.71 \pm 0.12 * *$ \\
\hline Urine $\mathrm{K}^{+}, \mathrm{mmol} / \mathrm{l}$ & $4.43 \pm 0.23$ & $15.36 \pm 0.80^{*}$ & $9.50 \pm 0.41 * *$ \\
\hline Plasma $\mathrm{K}^{+}$, mmol/1 & $5.71 \pm 0.21$ & $4.36 \pm 0.27 *$ & $5.86 \pm 0.36^{* *}$ \\
\hline
\end{tabular}

Note: significant differences comparing to: intact control group $-*(\mathrm{P}<0.05)$; cisplatin-induced AKI group $* *(\mathrm{P}<0.05)$. 


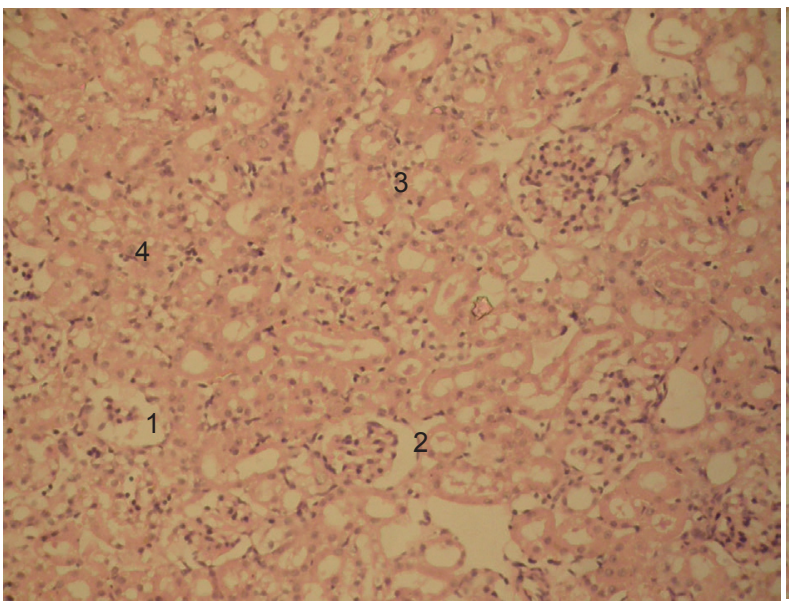

A

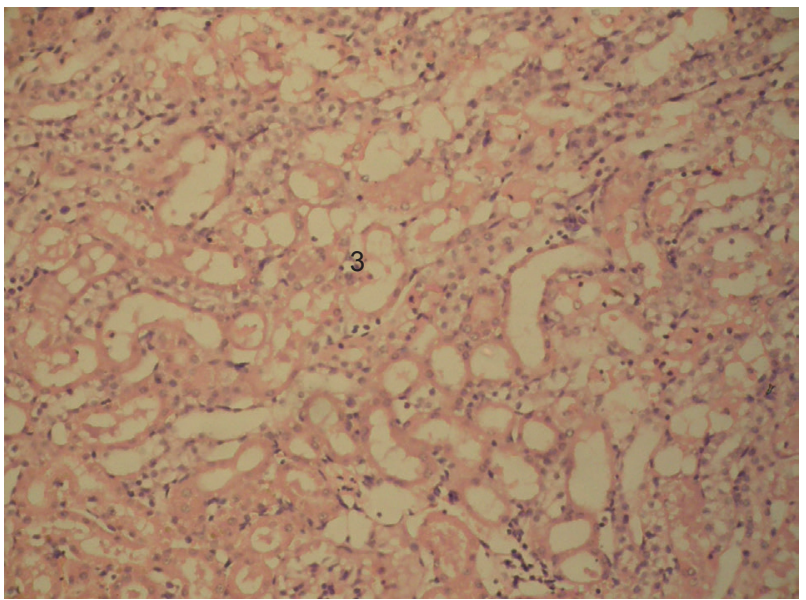

B

Fig. 1. Photomicrograph of kidney section (A - cortex, B - medulla) of rat with cisplatin-induced acute kidney injury. Glomerular atrophy (1), dilation of Bowman's space (2), epithelial degeneration (3), epithelial necrosis (4). Staining with haematoxylin and eosin. 100x magnification

state reversible hydropic swelling. In the part of glomeruli, the signs of atrophy are observed with a 2-fold decrease in the total number of cells comparing to control. Besides, there is a moderate swelling of mesangium and dilation of the Bowman's lumen in some glomeruli. Lumen of renal tubules are dilated, there are single hyaline casts.

The positive effect of melatonin use manifested in the prevention of a significant damage to rat kidneys, which is confirmed by an improvement of their functional state as compared to non-treated animals with AKI (see Table). In the group of animals administered with melatonin, the diuresis increased by 1.8 times, accompanied by a significant rise in GFR by 2.6 times, indicating the prevention of the oliguria development and, accordingly, a better prognosis comparing to untreated animals. Use of melatonin caused a 2-fold increase in creatinine excretion as compared with the AKI group, which prevented the development of hyperazotemia. The protective effect of melatonin on tubular cells is confirmed by a decrease in proteinuria - the urine protein level decreased by 1.7 times, protein excretion - by 2.5 times. It was established, that administration of melatonin in the prophylactic-therapeutic regimen resulted in the prevention of significant sodium loss, confirmed by the preservation of the fractional excretion of sodium at the level of control values, with the corresponding increase in the absolute sodium reabsorption by 2.7 times. Likewise, an increase in the indices of both proximal and distal transport of sodium ions by 2.8 and 1.9 times, respectively, was observed, indicating the maintenance of the tubular-tubular balance. Use of melatonin also caused an improvement in the potassium balance: the excretion of potassium ions was significantly reduced by 2.4 times, which prevented the development of hypokalemia and is confirmed by the normalization of the plasma potassium level. Moreover, there was a decrease in excretion of titrated acids by 1.4 times and activation of ammoniagenesis, which led to a tendency to increase urine $\mathrm{pH}$.

The obtained data are confirmed by the results of the morphological study (Fig. 2). The protective effect of melatonin resulted in reducing the number of necrotic cells to $4.5 \%$, while dystrophic changes in the form of reversible hydropic swelling are seen in $85 \% \pm 1.3 \%$ epithelial cells of proximal tubules, and only $1 \%$ of the cells are in a state of hydropic vacuolation. Tubular lumen is free, not dilated. Melatonin prevented damage to glomeruli, which 


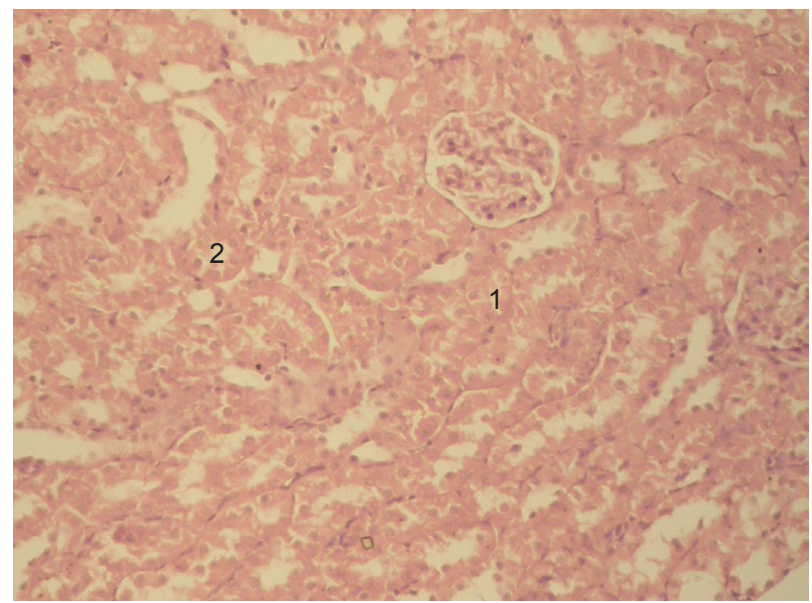

A

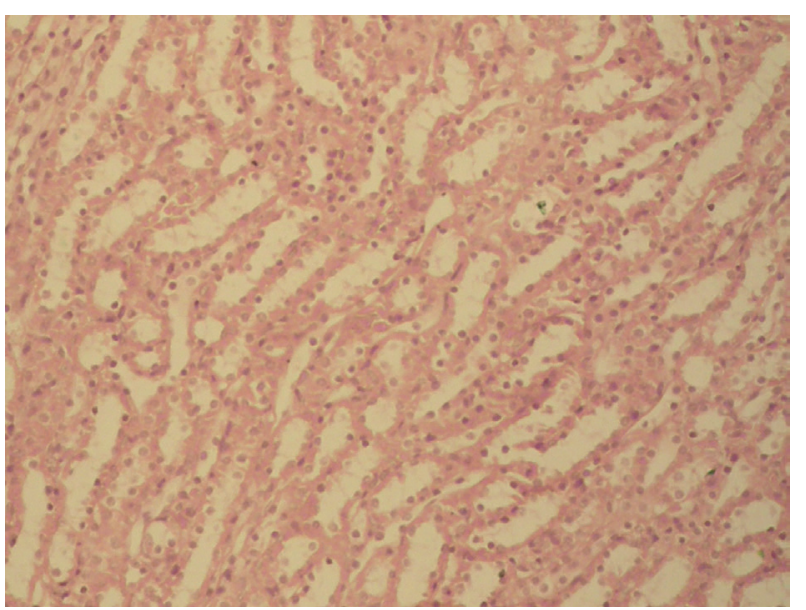

B

Pис. 2. Photomicrograph of kidney section (A - cortex, B - medulla) of rat with cisplatin-induced acute kidney injury, administered with melatonin, $5 \mathrm{mg} / \mathrm{kg}$. Epithelial degeneration (1), epithelial necrosis (2). Staining with haematoxylin and eosin. 100x magnification

have no signs of morphological changes.

The results of this study confirm the nephroprotective activity of melatonin in conditions of cisplatin-induced toxic kidney injury, which manifested in improving the morphofunctional state of kidneys due to the cytoprotective effect of melatonin on tubular cells, and is confirmed by a significant increase in diuresis and GFR, a decrease in azotemia, proteinuria, loss of sodium and potassium ions with urine, as well as the limitation of the degree and prevalence of histopathological changes.

In our opinion, these nephroprotective effects may be explained first and foremost by the powerful antioxidant properties of this hormone at the level of the renal tubular cells - both direct antioxidant effect of the "scavenger" of free radicals, and indirect as a stimulator of antioxidant enzymes activity $[1,7,26]$. Probably, the anti-inflammatory effects of melatonin as a result of the inhibition of lipoxygenase activity may also contribute to the cytoprotective action of melatonin in conditions of cisplatin-induced AKI $[12,13]$.

\section{CONCLUSIONS}

Use of melatonin at a dose of $5 \mathrm{mg} / \mathrm{kg}$ in the prophylactic-therapeutic treatment regimen shows a nephroprotective effect in conditions of cisplatin-induced acute kidney injury, which manifests by the amelioration of excretory, ionregulatory, and acid-regulatory kidney function, as well as the restriction of the morpho-structural alterations in kidney tissue.

The findings reveal new prospects for the study of melatonin as a drug with nephroprotective activity in a wide range of renal pathology.

The authors of this study confirm that the research and publication of the results were not associated with any conflicts regarding commercial or financial relations, relations with organizations and/or individuals who may have been related to the study, and interrelations of coauthors of the article.

\section{Є.А. Дудка, Т.С. Щудрова, А.Є. Петрюк, I.I. Заморський}

\section{МОРФОФУНКЦІОНАЛЬНИЙ СТАН НИРОК ЩУРІВ ЗА УМОВ КОРЕКЦІї МЕЛАТОНІНОМ ЦИСПЛАТИНІНДУКО- ВАНОГО ГОСТРОГО ПОШКОДЖЕННЯ НИРОК}

В експериментах на лабораторних нелінійних білих статевозрілих щурах досліджено вплив мелатоніну (5 мг/кг) на морфофункціональний стан нирок за умов розвитку 
цисплатин-індукованого гострого пошкодження нирок. Виявлено, що одноразове введення цисплатину дозою 6 мг/кг призводить до некрозу та поширених дегенеративних змін канальцевих клітин з розвитком олігуричної форми токсичної нефропатії, що супроводжується зменшенням діурезу у 2,9 раза, зниженням швидкості клубочкової фільтрації у 5 разів, збільшенням концентрації креатиніну в плазмі крові у 2,2 раза, значною протеїнурією та порушенням реабсорбційної здатності нефронів. Застосування мелатоніну у профілактично-лікувальному режимі введення виявляє цитопротекторний ефект щодо епітеліоцитів ниркових канальців, значно обмежуючи ступінь та поширеність гістопатологічних змін, та, відповідно, попереджуючи розвиток олігурії, на що вказує вірогідне зростання діурезу у 1,8 раза, швидкості клубочкової фільтрації - у 2,6 раза порівняно зі значеннями у нелікованих тварин; ретенційної азотемії, гіпокаліемії та значних втрат іонів натрію, зменшуючи протеїнурію у 1,7 раза та активуючи амонійгенез. Отримані результати досліджень обгрунтовують перспективність подальшого вивчення нефропротекторного потенціалу мелатоніну за умов ниркової патології різного генезу.

Ключові слова: цисплатиніндуковане гостре пошкодження нирок; мелатонін; нефропротекція.

Вищчии державний навчальний заклад Украӥни «Буковинський державний медичний університет», Чернівиі; е-mail: igor.zamorskii@gmail.com

\section{Е.А. Дудка, Т.С. Щудрова, А.Е. Петрюк, И.И. Заморский}

\section{МОРФОФУНКЦИОНАЛЬНОЕ СОСТОЯ- НИЕ ПОЧЕК КРЫС В УСЛОВИЯХ КОРРЕКЦИИ МЕЛАТОНИНОМ ЦИСПЛА- ТИНИНДУЦИРОВАННОГО ОСТРОГО ПОВРЕЖДЕНИЯ ПОЧЕК}

В экспериментах на лабораторных нелинейных белых половозрелых крысах исследовано влияние мелатонина (5 мг/кг) на морфофункциональное состояние почек в условиях развития цисплатин-индуцированного острого повреждения почек. Обнаружено, что однократное введение цисплатина в дозе 6 мг/кг приводит к некрозу и распространенным дегенеративным изменениям канальцевых клеток с развитием олигурической формы токсической нефропатии, что сопровождается уменьшением диуреза в 2,9 раза, снижением скорости клубочковой фильтрации в 5 раз, увеличением концентрации креатинина в плазме крови в 2,2 раза, значительной протеинурией и нарушением реабсорбционной способности нефронов. Применение мелатонина в профилактически-лечебном режиме введения оказывает цитопротекторный эффект по отношению к эпителиоцитам почечных канальцев, значительно ограничивая степень и распространенность гистопатологичних изменений, и, соответственно, предупреждая развитие олигурии, на что указывает достоверный рост диуреза в
1,8 раза, скорости клубочковой фильтрации - в 2,6 раза по сравнению со значениями у нелеченных животных; ретенционной азотемии, гипокалиемии и значительных потерь ионов натрия, уменьшая протеинурию в 1,7 раза и активируя аммонийгенез. Полученные результаты исследований обосновывают перспективность дальнейшего изучения нефропротекторного потенциала мелатонина в условиях почечной патологии различного генеза.

Ключевые слова: цисплатининдуцированное острое повреждение почек; мелатонин; нефропротекция.

\section{REFERENCES}

1. Sharman EH, Bondy SC. Melatonin: A safe nutraceutical and clinical agent. Nutraceuticals: Efficacy, Safety and Toxicity. 2016;501-9.

2. Pishak VP, Bulyk RYe, Zamorskii II, Tkachuk SS. Pineal gland: pathomorphology, pathological physiology, pharmacology. Chernivtsi; 2012. [Ukrainian].

3. Bonnefont-Rousselot D, Collin F. Melatonin: Action as antioxidant and potential applications in human disease and aging. Toxicology. 2010;278(1):55-67.

4. Reiter R, Rosales-Corral S, Tan D, Jou M, Galano A, $\mathrm{Xu}$ B. Melatonin as a mitochondria-targeted antioxidant: one of evolution's best ideas. Cell Mol Life Sci. 2017;74(21):3863-81.

5. Espino J, Rodriguez A, Pariente J. Melatonin and Oxidative Stress in the Diabetic State: Clinical Implications and Potential Therapeutic Applications. Curr Med Chem. 2018;25.

6. Ničković V, Novaković T, Lazarević S, Šulović L, Živković Z, Živković J et al. Pre- vs. post-treatment with melatonin in CCl4-induced liver damage: Oxidative stress inferred from biochemical and pathohistological studies. Life Sci. 2018;202:28-34.

7. Majidinia M, Sadeghpour A, Mehrzadi S, Reiter R, Khatami N, Yousefi B. Melatonin: A pleiotropic molecule that modulates DNA damage response and repair pathways. J Pineal Res. 2017;63(1):e12416.

8. Lowes D, Webster N, Murphy M, Galley H. Antioxidants that protect mitochondria reduce interleukin- 6 and oxidative stress, improve mitochondrial function, and reduce biochemical markers of organ dysfunction in a rat model of acute sepsis. Br J Anaesth. 2013;110(3):472-80.

9. Andersen L, Gögenur I, Rosenberg J, Reiter R. The Safety of Melatonin in Humans. Clin Drug Investig. 2015;36(3):169-75.

10. Bai X, He T, Gao J, Liu Y, Liu J, Han S et al. Melatonin prevents acute kidney injury in severely burned rats via the activation of SIRT1. Sci Rep. 2016;6(1):32199.

11. Elbe H, Vardi N, Esrefoglu M, Ates B, Yologlu S, Taskapan C. Amelioration of streptozotocin-induced diabetic nephropathy by melatonin, quercetin, and resveratrol in rats. Hum Exp Toxicol. 2014;34(1):100-13.

12. Fadda L, Mohamed A, Ali H, Hagar H, Aldossari M. Prophylactic administration of carnosine and melatonin abates the incidence of renal toxicity induced by an over 
dose of titanium dioxide nanoparticles. J Biochem Mol Toxicol. 2018;32(3):e22040.

13. Hill N, Fatoba S, Oke J, Hirst J, O’Callaghan C, Lasserson D et al. Global Prevalence of Chronic Kidney Disease - A Systematic Review and Meta-Analysis. PLoS One. 2016;11(7):e0158765.

14. Hayati F, Hossainzadeh M, Shayanpour S, AbediGheshlaghi Z, Beladi Mousavi SS. Prevention of cisplatin nephrotoxicity. J Nephropharmacol. 2016;5(1):57-60.

15. Oh G, Kim H, Shen A, Lee S, Khadka D, Pandit A et al. Cisplatin-induced Kidney Dysfunction and Perspectives on Improving Treatment Strategies. Electrolyte Blood Press. 2014;12(2):55.

16. Kandhare A, Mukherjee A. Efficacy of Antioxidant Supplements on Prevention and Amelioration of Cisplatin-Induced Nephrotoxicity: A Systematic Review and
Meta-Analysis of Randomized Controlled Trials. Value Health. 2017;20(9):A895.

17. Kilic U, Kilic E, Tuzcu Z, Tuzcu M, Ozercan I, Yilmaz $\mathrm{O}$ et al. Melatonin suppresses cisplatin-induced nephrotoxicity via activation of $\mathrm{Nrf}-2 / \mathrm{HO}-1$ pathway. Nutr Metab. 2013;10(1):7.

18. Zemła A., Grzegorek I., Dzięgiel P., Jabłońska K. Melatonin Synergizes the Chemotherapeutic Effect of Cisplatin in Ovarian Cancer Cells Independently of MT1 Melatonin Receptors. In Vivo. 2017;31(5):801-9.

19. Singh AP, Junemann A, Muthuraman A, Jaggi AS, Singh $\mathrm{N}$, Grover K et al. Animal models of acute renal failure. Pharmacol Reports. 2012;64(1):31-44.

20. Kamyshnikov VS. Manual on clinical biochemical studies and laboratory diagnostics. 3rd ed. Moscow; 2009. [Russian].

Received 05.07.2018 